\title{
12. Measuring Economic Progress: From Political Arithmetick to Social Accounts $^{1}$
}

\author{
Ian Castles
}

I am delighted to give the Eighth Colin Clark Memorial Lecture. The Department of Economics, the Economic Society of Australia in Queensland and the Queensland Treasury are to be congratulated upon their initiative and their continuing support, and I give special thanks to the department for honouring me with the invitation to present the 1998 lecture, and for its welcome to me in recent days.

Previous speakers in the series have contributed much to the development of our knowledge of the work of one of the most influential scholars of the century, and our understanding of its significance. But there is much more still to be learned. As Jim Perkins and Alan Powell observed in their 'affectionate memoir' in 1990, 'it would take a small army of biographers, historians of economic thought and bibliographers to evaluate properly the man, economist, scholar and polemicist whose works span more than half a century'. ${ }^{2}$

The particular perspective on Clark's life work which I have chosen to explore in today's lecture is that of its connection with the art and science of 'political arithmetick': the term coined by William Petty in the late seventeenth century to denote the systematic assembly of numerical information for public policy purposes.

Colin Clark himself acknowledged his indebtedness to, and affinity with, the political arithmeticians in his preface to the first edition of Conditions of Economic Progress:

...economics was started on the right lines by Gregory King and Sir William Petty at the time of that astonishing flowering of the English scientific spirit in the later 17 th century. ... We need to return to the spirit of those two brilliant pioneers from whom even now we have much to learn. ${ }^{3}$

\footnotetext{
1 First given as the Eighth Colin Clark memorial lecture of The University of Queensland in October 1998.

2 Perkins, JON and Powell, Alan A (1990). 'Colin Clark, 1905-1989: An Affectionate Memoir', The Economic Record December: 329-341.

3 Clark, Colin (1940). Conditions of Economic Progress, London, Macmillan.
} 
We can only speculate on the origins of Clark's interest in these political arithmeticians. It may not be merely coincidental that he began his postsecondary career at Brasenose College, Oxford - the College at which Petty had been vice-principal nearly three centuries earlier. Clark was to note with relish that in his (Clark's) day, Brasenose 'had a great reputation for athletic prowess, philistinism and drinking'. ${ }^{4}$

It is also possible that Clark's interest in these 'brilliant pioneers' was fired by his brief association with AM (later Sir Alexander) Carr-Saunders, who as Professor of Social Science at Liverpool supervised Clark's work on the Social Survey of Merseyside in 1929. Clark was later to acknowledge that he had 'learnt a great deal from [Carr-Saunders'] highly original work on sociology and on demography', ${ }^{5}$ and he may well have learned at this time of the seminal contributions of Petty and King to the development of demography as the central core of what was then 'political arithmetick' and what might now be termed 'social science'.

Petty was a polymath. He became professor of anatomy at Oxford at the age of 28, and in the following year 'went to Ireland as physician-general to the army, which was no sinecure in a country ravaged by the plague and other lethal epidemic diseases'. He was a 'persistent inventor', pursuing his design for a twin-hulled ship through four prototypes. One of the founders of the Royal Society, 'he read a number of communications to the Society on topics varying from dyeing practices in the clothing trade to the testing of mineral waters and (achieved) a formidable and serious literary output on economic, demographic, naval, medical and scientific subjects'. As political arithmetician, Petty's achievement is summarised by Phyllis Deane, in the International Encyclopedia of the Social Sciences in the following terms:

Petty's claim to fame as an economist lies not so much in his originality or his theoretical ability as in his analytical skill. His insistence on measurement and his clear schematic view of the economy make him the first econometrician, and he was constantly evolving and using concepts and analytical methods that were in advance of his time. His evaluation of the gain from foreign trade in 'Another Essay in Political Arithmetick Concerning the Growth of the City of London' ... is based on a statement of the benefits of the division of labor and specialization and was written a century before Adam Smith's famous account. ... He was the author of the first known national income estimates ... some of the calculations in his Treatise of Taxes and Contributions and elsewhere are essentially exercises in what is now called 'cost-benefit analysis'. He was the first writer, so far as we know, to grasp the concept of the velocity of money... ${ }^{6}$ 
Gregory King is less well known. At the time that Colin Clark described him as a 'brilliant pioneer', and for at least another quarter-century, he did not rate an entry in the Encyclopedia Brittanica.

Like the higher-profile Petty, King was a polymath. He 'was a well-informed topographer and surveyor', and was the designer of the district of Soho in London, 'whose streets and squares were all projected by him, and most of the first articles for building thereof'. He supported himself for many years as a mapmaker and engraver, including by the preparation of maps of London and Westminster at a scale of 100 feet to the inch. He is also recorded as being 'a skilled and well-known genealogist', 'a successful practising accountant' and a teacher of bookkeeping. He learned to play the violin, and 'was convivial to the point of organising an annual meeting of persons bearing the surname "King"' ${ }^{7}$ But his lasting fame is as a political arithmetician, and Phyllis Dean's assessment is again worth quoting:

King was a scholar rather than a politician. Perhaps this was why he never published his estimates, being content to make them freely available as a basis for economic policy making or analysis ... He was primarily interested in finding the exact truth about the dimensions of the national economy, so far as the available data would let him. It is evident from the notes and communications which have survived that he was completely honest about the limitations of his material and amazingly methodical in his use of it. And the more modern scholars have probed his methods and uncovered new sources of his notes, the more they have tended to admire his results. His famous 'Scheme of the Income and Expenses of the Several Families of England', given in his Natural and Political Observations and Conclusions Upon the State and Condition of England (1696), and his international comparisons of national income and expenditure for England, France, and Holland in his Of the Naval Trade of England $A^{\circ} 1688$ and the National Profit Then Arising Thereby (1697) were based essentially on guesswork, but as explicit statements of the views of a particularly well informed observer they are profoundly revealing. They ... became benchmark data of immense value to students of long-term growth.

All King's estimates were made with an accountant's meticulous concern for internal consistency, and in this respect his national income estimates were in advance of any calculations made in this field until the mid-twentieth century. It is possible to extract from [his] national income and balance of payments estimates ... a complete, articulated set

7 Glass, DV (1965). 'Two Papers on Gregory King' in Glass, DV and Eversley, DEC Population in History: Essays in Historical Demography, London, Edward Arnold (Publishers). 
of double-entry social accounts as well as an abundance of detail on the content of national income, output, and expenditure in 1688 and 1695. He also made estimates of the national capital, its content and its rate of increase through the seventeenth century. His population estimates were based on careful analyses of actual enumerations for particular places, corrected for technical errors and adjusted to a national basis, on assumptions that modern demographers (basing their judgements on the results of nineteenth-century census enumerations) have found to be both consistent and plausible. His schedule of the relation between changes in the price of wheat and deviations from the normal wheat harvest ... represents a piece of demand analysis of a kind that we find in no other source until the early twentieth century. ${ }^{8}$

In 1966, a full quarter of a century after Colin Clark's invocation of Gregory King's name in the preface to his own great pioneering work, the English historical demographer Peter Laslett wrote of King in the following terms:

However much the contemporary student of historical social structure sees himself as an explorer of unknown territory, he feels that King has been there before him, in the 1690s ... (I)t has only now begun to be realised what a remarkable feat it was for him to have drawn up the one and only attempt at a complete social description ever made anywhere in pre-industrial Europe, and to have done so 150 years before the Registrar-General began to collect the mass of complicated evidence which we now think is necessary for the purpose..$^{9}$

It is not surprising that Colin Clark was attracted to the subject matter of the works of Petty and King: in essence, they were seeking to answer the same demographic, sociological and economic questions which Clark had been addressing for more than a decade, and was to continue to address for more than 50 years.

But Clark's plea to his contemporaries, in the preface to his great work, did not relate to the subject matter studied by the political arithmeticians: his reference was to the 'scientific spirit in the later 17th century' (emphasis added), and it was from this 'spirit' of Petty and King that he believed 'even now we have much to learn'.

Clark saw himself as possessing this 'scientific spirit' - as being, in fact a 'scientist'. Explaining to Chris Higgins why he had never stood for Parliament in Australia, after standing three times as a Labour candidate in Britain, Clark said

8 Deane, Phyllis (1969). 'King, Gregory' in International Encyclopedia of the Social Sciences, vol 8: 385-86.

9 Laslett, Peter (1973). 'Introduction' to the Earliest Classics, Gregg. 
...it had become clear to me I had not got the right personality for politics. It's a different world, really. I am, or tried to be, a scientist, whereas politicians have to deal with action. It is a fundamental distinction. ${ }^{10}$

And Colin Clark drew another fundamental distinction between 'economic scientists' and 'economic theorists'. Here is the argument, as developed in the 1940 preface which has already been cited:

The hard scientific discipline has yet to be learned, that all theories must constantly be tested and retested against observed facts, and those which prove wrong ruthlessly rejected. Theory has a valuable, indeed an essential, part to play in the development of economic science. But it must be theory which respects facts, not tries to supersede them. ...there is room for two or three economic theorists in each generation, not more ... The rest of us should be economic scientists, content steadily to lay stone upon stone in building the structure of ordered knowledge. ${ }^{11}$

One of the fascinating pieces of information uncovered by George Kenwood and Alan Lougheed in their 'official history' of Economics at the University of Queensland is that a Department of History and Economic Science was projected as part of the Faculty of Arts at this University in $1911 .{ }^{12}$ There was in fact, nothing unusual about this terminology in the first half of the century.

In his great work Wealth and Welfare, published in 1912 and soon prescribed at the University of Queensland, AC Pigou said that:

The methodological principle at the basis of economic science, and which distinguishes it from the other social sciences, is the reference which it makes to a measure, mainly money. ${ }^{13}$

The probable reason for the contraction of 'economic science' to 'economics' is also given in Wealth and Welfare Pigou explained that the

purpose of economic investigation ... is not primarily scientific, if by science we intend the single-eyed search for knowledge for its own sake. It is rather practical and utilitarian, concerned chiefly to lay bare such parts of knowledge as may serve, directly or indirectly, to help forward the betterment of social life. Hence, the failure of economic welfare to act as a barometer of total welfare is of slight importance. For what we wish to learn is, not how large welfare is, or has been, but how its magnitude would be affected by the introduction of causes, which it is in the power of statements or private persons to call into being. ${ }^{14}$

10 Higgins, Christopher I (1989). 'An Interview: Colin Clark', The Economic Record, December: 297.

11 Clark, Colin (1940). Op cit: xy.

12 Kenwood, AG and Lougheed, AL (1997). Economics at the University of Queensland 1912-1997: 1.

13 Pigou, AC (1912). Wealth and Welfare: 8.

14 Ibid: 4. 
In March 1930, at the age of 24, Colin Clark was suddenly placed in a position of potential influence over 'statesmen' with the power to introduce 'causes' which would enhance the welfare of the people of Great Britain. To his complete surprise, Clark was appointed to the staff of the newly formed Economic Advisory Council. For Clark, it was a deeply disillusioning experience. As he was to recall nearly 40 years later, the Council was 'a weird and wonderful organisation indeed'. It was chaired by the Prime Minister, Ramsay MacDonald, and included the Chancellor of the Exchequer, Philip Snowden, and three other Ministers. Among the 15 other members were three economists (GDH Cole, JM Keynes and Sir Josiah Stamp); a physicist and a geneticist who 'knew nothing whatever about economics' but contributed 'lengthy memoranda to the Council's proceedings'; some prominent bankers and businessmen 'who talked far too much, mostly about their own troubles'; Ernest Begin, leader of the Transport and General Workers' Union; and the economic historian RH Tawney. ${ }^{15}$

Before long, Clark was to recall, 'we were engaged in interminable committees about the need for "training more biologists", and for international measures of locust control'. Meanwhile - and this information comes not from Clark but from the history of the Council published in 1977 - the Treasury refused to buy an adding machine for Colin Clark. ${ }^{16}$

Meanwhile, the economic situation was rapidly worsening and it was becoming increasingly apparent that 'the Economic Advisory Council, as then constituted, was not the appropriate body to advise on what was, after all, an economic problem'. And so a committee of [five] economists, chaired by Keynes, was appointed to review 'the whole problem of the Great Depression'.

Importantly for our story, Colin Clark was 'permitted to attend most ... of the meetings' of this Committee and 'to circulate ... some calculations I had made, comparing the industrial production index with the employment figures for manufacturing industries ... indicating that product per man-year had been showing a moderate rate of improvement during the 1920s; thus, amongst other things, justifying some rise in real wages'. ${ }^{17}$

As Clark told Chris Higgins in 1988, his idea would now be seen as an elementary one, but 'in those days it was novel...'. ${ }^{18}$ Keynes was impressed, and encouraged Clark to develop the work. Keynes also recommended him for the lectureship in statistics at Cambridge which Clark took up in 1931 and retained until he came to Australia in 1937.

Even more importantly, Keynes gave strong support to the publication of Clark's first book The National Income 1924-1931. Recommending the manuscript to

15 Clark, Colin (1977). Op cit: 85.

16 Howson, Susan and Winch, Donald (1977). The Economic Advisory Council 1930-1939: 25.

17 Clark, Colin (1977). Op cit: 87-88.

18 Higgins Christoher I (1989). Op cit: 298. 
Daniel Macmillan, Keynes said 'that Clark's work, on this and allied subjects, is quite outstanding and that he is likely to become the recognised authority, in the course of time. ...Clark is, I think, a bit of a genius - almost the only economic statistician I have ever met who seems to me quite first class. ${ }^{19}$

Keynes was equally enthusiastic after reading the finished book. In a letter to Clark on 2 January, 1933, he wrote:

I have just finished reading your book carefully ... I think that it is excellent. An enormous step forward. ...You have quite convinced me that gross output, gross investment, gross savings, etc. is the natural way to work and not with the net, and I have been re-writing my definitions and equations on those lines. I am sure it is an improvement.

Keynes proceeded to explore what he described as 'an interesting possibility' relating to the size of the multiplier and the normal growth rate, which had been suggested to him by the tables in the last chapter of Clark's book. And Clark responded with further calculations and the observation 'this really is rather fascinating. It certainly beats Physics'.

We can guess that Clark and Keynes had at some time talked about Clark's scientific background: his degree at Oxford had been in chemistry, and the subject of his thesis had been the radio-chemistry of uranium and thorium.

Some years later, Keynes was to pen his famous lines about Stanley Jevons as

...the first theoretical economist to survey his material with the prying eyes and fertile, controlled imagination of the natural scientist. ... It is remarkable, looking back, how few followers and imitators he had in the black arts of inductive economics in the fifty years after 1862. But today [that is, 1936] he can certainly claim an unnumbered progeny, though the scientific flair which can safely read the shifting sands of economic statistics is no commoner than it was. ${ }^{20}$

Clark liked Keynes' phrase about the 'prying eyes and fertile, controlled imagination of the natural scientist', and knew that it applied to some degree also to himself. But it is doubtful whether he realised the closeness of the parallels between himself and Jevons.

First, they had both begun their post-secondary education with the study of chemistry.

19 Keynes, JM (1971-89). The Collected Writings of John Maynard Keynes, (30 vols.) All of the cited quotations in correspondence with or about Colin Clark are from The Collected Writings.

20 Keynes, JM (1951). 'William Stanley Jevons' in Essays in Biography. 2nd ed: 268. 
Secondly, they had both, at the age of 23, been engaged in social surveys of cities - Jevons in Sydney in his remarkable solo effort which survives in manuscript in the Public Library of New South Wales - but regrettably remains unpublished, Clark as a member of the staff of the New Social Survey of London which attempted to reproduce Charles Booth's survey in the 1890s - a survey which Professor Graeme Davison of Monash has shown may well have been modelled in important respects on Jevons' study. ${ }^{21}$

Thirdly, Jevons and Booth were both born in Liverpool, where Clark was to work with Carr-Saunders on another social survey.

Fourthly, both Jevons and Clark turned heavily towards quantification - towards political arithmetic - and both produced, at the age of 26, path-breaking studies, which earned Keynes' admiration. Both of them were writing alone without support. We have already seen what Keynes said about Clark's pioneering study on the national income: here is what he had to say about Jevons' study, A Fall in the Price of Gold Ascertained and its Social Effects Considered.

For unceasing fertility and originality of mind applied with a sure touch and unfailing control of the material, to a mass of statistics, involving immense labours for an unaided individual ploughing his way through with no precedents and labour-saving devices to relieve his task, this pamphlet stands unrivalled in the history of our subject. ${ }^{22}$

There are still other parallels. Both Jevons and Clark worked as public servants in Australia, both of them acknowledged freely that their official duties were not heavy, and both of them used the resulting free time to pursue innovative scientific work with enormous energy and skill.

Finally, and importantly for our theme, both were deeply interested in the work of their predecessors, including the political arithmeticians of the seventeenth century. In his Theory of Political Economy, praised by Keynes as 'the first modern book on economics', Jevons reported that, although the celebrated law of demand

is 'commonly attributed' to King, he was unable to find it in the full reproduction of King's Observations contained in George Chalmer's Estimate of the Comparative Strength of Great Britain (1802). The fact that Davenant elsewhere made full acknowledgement to King also led Jevons to suggest that the law is 'perhaps' due to Davenant. ${ }^{23}$

21 Davison, Graeme (1996) 'The unsociable sociologist - WS Jevons and his Survey of Sydney, 1858'. Conference on 'Natural Sciences and Social Sciences', Humanities Research Centre, Australian National University, 9 September.

22 Keynes, JM (1951). Op cit: 271.

23 Creedy, J (1986). 'On the King-Davenant “Law” of Demand', Scottish Journal of Political Economy: 194-95. 
Jevons went on to observe that he knew

nothing more strange and discreditable to statists and economists than that in so important a point as the relations of price and supply of the main article of food, we owe our most accurate estimates to writers who lived from one to two centuries ago. ${ }^{24}$

Let us now return to 1933, when Clark wrote with excitement to Keynes that the work on which they were jointly engaged 'certainly beats physics'. Soon after this, Clark contributed an important essay to a collection of studies of the economic problem which was planned and edited by GDH Cole. The following extracts convey the flavour of Clark's thinking at this time:

[In his last] two budgets Mr Neville Chamberlain has resignedly faced, as if it were something to do with the weather, conditions of declining income and production...

What neither of our British Chancellors - iron or wooden - seemed to have realised is the effect which government policy can have on the size of the national income, as well as the effect which a decline in the national income, fatalistically accepted, must perforce have upon government policy...

...If somebody would invent a new system of mathematics whereby every country should import less and export more, he would be doing the world a great service; but under our present rules of arithmetic it is impossible. The balances of trade of all the countries in the world, some being positive and some being negative, must of necessity add up to zero...

...The biggest scope for public investment lies in the restoration of the activity of municipal housing and the rapid proceeding with slum clearance schemes, road programs, rural water supply and sewage, small holdings and afforestation, and a great deal of new school building and replacement...

Everyone of them represents work which would permanently enrich the country, and the fact that we prefer to leave labour and resources idle rather than to undertake such work, because as we say there is not enough money in the country, merely proves that we are all mad.

A really big program of public works would lead to a big consequential demand for productive materials such as cement, steel and bricks. The 
effect of increasing the purchasing power of the workers would also be to improve the demand for a great many other commodities of staple consumption...

...(T)he main planks in a program of monetary recovery ... must be a big policy of public investment, some plan of recovery for private investment, and the expansion of the purchasing power of those who need it most, by social services and by a forward wage policy which keeps pace with technical progress. ${ }^{25}$

Keynes' appreciation of Colin Clark's capacities was again evident in an exchange of letters between them in $1938 .{ }^{26}$ Clark wrote to Keynes from New Zealand on 1 February, saying that his 'address till August will be University of Western Australia' and concluding:

I am reaching the conclusion I want to stay in Australia. People have minds which are not closed to new truths, as the minds of so many Englishmen are: And with all the mistakes Australia has made in the past, I still think she may show the world, in economics, politics, education and technology, in the next twenty years.

In his reply, Keynes said that he was 'rather dismayed' with this paragraph, 'though not taken entirely by surprise'. He urged Clark to return to Cambridge first, noting the necessity of laying 'the foundations for a proper department of statistical realistic economics' at that University and strongly implying that Clark should be its head.

The rest, as they say is history. Clark rejected the offer of a professorship in Adelaide but accepted an offer from the Queensland government. He was a public servant in this State for 14 years, before returning to academia for the remainder of a long and productive career for which he should have received the Nobel Prize in Economics - as Heinz Arndt said in the obituary for the Academy of the Social Sciences in Australia. ${ }^{27}$ And the department of 'statistical realistic economics' was in due course established at Cambridge as the Department of Applied Economics under Richard Stone, who had been Clark's student. Stone played the leading role in the development of the internationally agreed System of National Accounts and for this and other contributions to 'statistical realistic economics' he did receive the Nobel Prize. But Colin Clark's legacy to us of 'statistical realistic economics' is no less rich and varied, and his injunction to economists to embrace 'the scientific tradition of the seventeenth century pioneers' is as apt today as it was in 1940.

25 Clark, Colin (1933). 'Investment, Savings and Public Finance' in Cole, GDH (ed.) What Everybody Wants to know about Money: A planned outline of monetary problems. London. Gollancz. 